\title{
Serum antioxidants and risk of rheumatoid arthritis
}

\author{
M Heliövaara, P Knekt, K Aho, R-K Aaran, G Alfthan, A Aromaa
}

\begin{abstract}
Objectives-Oxygen free radicals have been implicated as mediators of tissue damage in patients with rheumatoid arthritis (RA). Thus it is possible that several micronutrients acting as antioxidants and free radical scavengers provide protection against RA. Serum alpha-tocopherol, beta-carotene, and selenium were studied for their associations with the risk of RA.

Methods-A case control study was nested within a Finnish cohort of 1419 adult men and women. During a median follow up of 20 years, 14 individuals initially free of arthritis developed RA. Two controls per each incident case were individually matched for sex, age, and municipality. Serum alpha-tocopherol, beta-carotene and selenium concentrations were measured from stored serum samples. An antioxidant index was calculated as the product of the molar concentrations of these three micronutrients.
\end{abstract}

Results-Elevated risks of $R A$ were observed at low levels of alpha-tocopherol, beta-carotene and selenium, but none of the associations were statistically significant. A significant association, however, was observed with a low antioxidant index ( $p$ for trend =0.03), the relative risk of RA between the lowest tertile and the higher tertiles of its distribution being $8 \cdot 3(95 \%$ confidence interval 1:0-71:0).

Conclusions-The results of the present study are in line with the hypothesis that

Social Insurance

Institution, PO Box 78, 00381 Helsinki, Finland A Aromaa

M Heliövaara

P Knekt

National Public Health Institute, Helsinki, Finland

K Aho

G Alfthan

Department of

Biomedical Sciences and Public Health,

University of Tampere, Tampere, Finland R-K Aaran

Correspondence to: Dr Heliövaara, Social Insurance Institution, PB 78, SF-00381 Helsinki, Finland.

Accepted for publication 4 October 1993 a low antioxidant level is a risk factor for RA.

(Ann Rheum Dis 1994; 53: 51-53)

Several different pathways can lead to increased formation of reactive oxygen metabolites in inflamed joints. ${ }^{1}$ This enhanced oxidation may play a significant role in the tissue-damaging and inflammationperpetuating process in rheumatoid synovium. ${ }^{2}$ Special emphasis has been placed on the so-called hypoxia-reperfusion injury. In this context, the first point of interest is that oxygen tension in the inflammatory synovial fluid is low. Under these conditions, movement of an inflamed joint is likely to cause sufficient pressure to result in transient ischaemia of the superficial synovial membrane. ${ }^{3}$ On restoration of blood supply, reactive oxygen species would then be generated by uncoupling of intracellular redox systems. In accordance with the enhanced oxidation, patients with rheumatoid arthritis (RA) exhibit abnormalities consistent with oxidative injury, such as end products of lipid peroxidation, oxidised ascorbic acid (dehydroascorbate) and an aberrant form of alpha1-antitrypsin in synovial fluid. ${ }^{2}$

There is an intrinsic defense system limiting free radical mediated tissue damage in which antioxidant micronutrients have an important role. Patients with RA have depressed serum levels of the antioxidant vitamins $\mathrm{E}$ and $\mathrm{A},{ }^{4}$ but no longitudinal studies have been carried out to explore the temporal order of the relationship. Thus there is reason to hypothesise that antioxidants can provide protection against RA. In this follow up study, we investigated serum alpha-tocopherol, betacarotene, and selenium levels for their prediction of RA.

\section{Patients and methods}

The Social Insurance Institution's mobile clinic unit carried out multiphasic health examinations in various parts of Finland in 1968-72. Serum concentrations of vitamins were determined from a sample of 1419 and of selenium from 1977 individuals who had initially served as a sex and age matched control group for cancer cases in a nested casecontrol study of micronutrients and incidence of cancer. ${ }^{5}$

\section{SERUM MICRONUTRIENT DETERMINATIONS}

Serum samples were drawn and kept frozen at $-20^{\circ} \mathrm{C}$ until they were thawed for alphatocopherol, beta-carotene, retinol, and selenium determinations in 1984. Retinol, beta-carotene, and alpha-tocopherol concentrations were determined simultaneously using high pressure liquid chromatography. ${ }^{6}$ The serum selenium concentrations were determined using electrothermal graphite furnace atomic absorption spectrometry. ${ }^{7}$ The coefficient of variation for the analytical reproducibility of the measured vitamin concentrations ranged from $2 \cdot 1 \%$ to $10.9 \%$ and the reliability coefficients for a four year intraindividual reproducibility ranged from 0.46 to $0 \cdot 65$. $^{5}$ The precision between series of the selenium method for a low and medium serum standard were $3.0 \%$ and $6 \cdot 8 \%$, respectively. 
Table 1 Mean (SD) level of serum micronutrients among incident cases of rheumatoid arthritis and matched controls

\begin{tabular}{|c|c|c|c|c|c|c|}
\hline \multirow{2}{*}{$\begin{array}{l}\text { Serum } \\
\text { micronutrient }\end{array}$} & \multicolumn{2}{|c|}{ Cases $(n=14)$} & \multicolumn{2}{|c|}{ Controls $(n=27)$} & \multirow{2}{*}{$\begin{array}{l}\text { Percentage } \\
\text { case control } \\
\text { difference }\end{array}$} & \multirow{2}{*}{$\begin{array}{l}p \text { value for } \\
\text { difference }\end{array}$} \\
\hline & mean & $(S D)$ & mean & $(S D)$ & & \\
\hline Alpha-tocopherol (mg/l) & $9 \cdot 02$ & $(2 \cdot 30)$ & 9.93 & $(2 \cdot 55)$ & 9 & $0 \cdot 29$ \\
\hline Beta-carotene $(\mu \mathrm{g} / \mathrm{l})$ & $92 \cdot 9$ & $(52 \cdot 1)$ & $150 \cdot 4$ & $(144 \cdot 5)$ & 28 & $0 \cdot 12$ \\
\hline Retinol $(\mu \mathrm{g} / \mathrm{l})$ & 685 & (135) & 685 & (111) & 0 & 0.99 \\
\hline Selenium $\left(\mu \mathrm{g} / \mathrm{l}^{1}\right.$ & $60 \cdot 0$ & $(12 \cdot 8)$ & $61 \cdot 2$ & $(12 \cdot 2)$ & 2 & 0.78 \\
\hline
\end{tabular}

${ }^{1}$ Number of cases is 27 and of controls 51 , respectively.

An antioxidant index was calculated as the product of the molar concentrations of alphatocopherol, beta-carotene and selenium. ${ }^{8}$ Retinol was not included in the index, because it has fewer antioxidant properties.

\section{IDENTIFICATION OF CASES AND MATCHED CONTROLS}

Morbidity and mortality of all examinees has been followed up continuously. Participants in the survey who later developed chronic arthritis were identified by linking the survey data with the Social Insurance Institution's population register up to the end of 1989 , using the unique social security code assigned to each Finnish citizen. ${ }^{9}$ In Finland, reimbursed drugs are provided for certain chronic diseases, including chronic inflammatory rheumatic diseases. Eligibility requires a comprehensive medical certificate written by the attending physician. These written documents were carefully reviewed to identify incident cases of RA. ${ }^{9}$

The population at risk consisted of participants who had no previous history of arthritis or other rheumatoid disease according to the Social Insurance Institution's population register or to a questionnaire administered at the baseline examination, and whose serum micronutrient levels had been determined. The median follow up time was 20 years. A total of 14 incident cases (eight men and six women) of RA occurred during the follow up in the final vitamin sample and 27 (15 men and 12 women) in the selenium sample. Two controls per case were selected by individual matching, using sex, municipality, and age as matching factors. Controls were drawn from the same municipality as the cases, and age was matched as closely as possible. The age range at the start of the follow up was 28-73 and the mean age both for cases and controls was 55 years. Matching for municipality also controlled for both the time of the baseline examination and for the duration of storage of serum samples.

Table 2 Relative risk of rheumatoid arthritis between the lowest and higher tertiles ${ }^{l}$ of serum micronutrient level

\begin{tabular}{|c|c|c|c|c|c|c|c|}
\hline \multirow{2}{*}{$\begin{array}{l}\text { Serum } \\
\text { micronutrient }\end{array}$} & \multicolumn{2}{|c|}{ Number of cases } & \multicolumn{2}{|c|}{ Number of controls } & \multirow{2}{*}{$\begin{array}{l}\text { Relative } \\
\text { risk }\end{array}$} & \multirow{2}{*}{$\begin{array}{l}95 \% \\
\text { confidence } \\
\text { interval }\end{array}$} & \multirow{2}{*}{$\begin{array}{l}\text { p value } \\
\text { for } \\
\text { trend }\end{array}$} \\
\hline & $\begin{array}{l}\text { Lowest } \\
\text { tertile }\end{array}$ & $\begin{array}{l}\text { Other } \\
\text { tertiles }\end{array}$ & $\begin{array}{l}\text { Lowest } \\
\text { tertile }\end{array}$ & $\begin{array}{l}\text { Other } \\
\text { tertiles }\end{array}$ & & & \\
\hline Alpha-tocopherol & 6 & 8 & 9 & 18 & 1.88 & $0.40-8.92$ & 0.24 \\
\hline Beta-carotene & 7 & 7 & 10 & 17 & $2 \cdot 30$ & $0 \cdot 43-12 \cdot 24$ & 0.13 \\
\hline Retinol & 5 & 9 & 9 & 18 & $1 \cdot 00$ & $0.18-5 \cdot 46$ & 0.96 \\
\hline Selenium & 12 & 15 & 18 & 33 & 1.63 & $0.57-4.69$ & $0 \cdot 11$ \\
\hline Antioxidant index & 9 & 5 & 9 & 17 & $8 \cdot 34$ & $0.98-71 \cdot 0$ & 0.03 \\
\hline
\end{tabular}

${ }^{1}$ Based on the distribution among controls. The lowest tertile was $\leqslant 8 \cdot 1 \mathrm{mg} / \mathrm{l}$ for alpha-tocopherol, $\leqslant 70 \mu \mathrm{g} / \mathrm{l}$ for beta-carotene, $\leqslant 620 \mu \mathrm{g} / \mathrm{l}$ for retinol, and $\leqslant 56 \mu \mathrm{g} / \mathrm{l}$ for selenium.
STATISTICAL METHODS

The significance of the differences in mean levels of serum micronutrients between cases and controls was tested by the paired $t$ test. The conditional logistic model ${ }^{10}$ was used to estimate the association between serum micronutrient levels and the risk of RA. The relative risks, estimated as odds ratios with $95 \%$ confidence intervals, were computed for tertiles of serum micronutrient concentrations. Linear trends between serum micronutrient levels and RA were tested with the likelihood ratio test based on the model.

\section{Results}

The mean level of serum beta-carotene was $92.9 \mu \mathrm{g} /$ litre among the future incident cases of RA and $150 \cdot 4: \mathrm{g} /$ litre among their controls; the difference was not statistically significant $(p=0 \cdot 12)$. The mean differences between cases and controls in serum levels of alphatocopherol and selenium were smaller, and there was no difference in serum retinol (table 1).

The relative risk of RA between the lowest tertile and higher tertiles of serum alphatocopherol, beta-carotene and selenium varied between 1.6 and 2.3 (table 2). None of these estimates differed significantly from unity. The index combining the serum levels of these three antioxidants, however, gave a relative risk of 8.3 and presented a significant gradient ( $p$ for trend $=0.03$ ). As adjusted for serum cholesterol, the relative risk was still as high as 5.8 but the gradient was not statistically significant ( $\mathrm{p}$ for trend $=0 \cdot 16$ ).

\section{Discussion}

The main finding of our study was that the risk of RA was significantly elevated among those with a low antioxidant index. The components of this index, serum concentrations of alphatocopherol, beta-carotene and selenium, predicted RA with relative risks of 1.6 to $2 \cdot 3$ for the lowest tertiles compared with higher concentrations. That the single estimates did not reach statistical significance may be due to the small number of incident cases of RA in our series. Although our study suggests a link, no firm conclusions can be drawn.

During the long period of storage between the baseline examination and the time for the serum analyses, loss due to storage has probably occurred especially for beta-carotene, but also in respect to alpha-tocoherol. ${ }^{5}$ Potentially these losses may have biased the results. However, a strong association between the serum concentration of beta-carotene and its intake, measured by a one year dietary recall method at the baseline, suggests that no notable bias exists in our series. ${ }^{11}$

The incident cases of RA were identified on the basis of their entitlement to specially reimbursed medication under the sickness insurance act by reviewing the medical certificates. Most of such cases met the American Rheumatism Association 1987 revised criteria for $\mathrm{RA},{ }^{12}$ the sensitivity of the 
sickness insurance data exceeds $90 \%$ for seropositive RA, ${ }^{9}$ and because of the careful review of the medical certificates it is reasonable to assume that the follow up of morbidity was also sufficiently specific for the purposes of the present study.

Depressed antioxidant levels before the onset of clinical RA may reflect a low dietary intake or an increased demand, related for instance to the pre-illness immunological process. Marker antibodies of RA, such as rheumatoid factor, can also precede the manifestation of arthritis by several years, focusing attention on pre-illness events in the pathogenesis of RA. ${ }^{13}$ It is possible that low antioxidant levels could be causally connected with development of the disease, but they may also only represent a distorted shadow of the actual pathogenetic factor. If there is a causal connection, failure in antioxidant protection may be manifested at the initiation of the immunological process or at a later phase, thereby augmenting the progression of an otherwise transient arthralgia or incipient arthritis.

In conclusion, our results agree with the hypothesis that antioxidant micronutrients provide protection against RA. Further prospective studies should be carried out in larger population samples with a sufficient number of incident cases. Firm evidence could only be obtained by demonstrating preventive effects of antioxidant supplements in intervention trials.
This study was supported in part by a grant from the Cancer Society of Finland.

1 Halliwell B, Hoult J R S, Blake D R. Oxidants, inflammation and anti-inflammatory drugs. FASEB $\mathscr{f}$ 1988; 2: 2867-73

2 Merry P, Winyard P G, Morris C J, Grootveld M, Blake D $R$. Oxygen free radicals, inflammation, and synovitis: the current status. Ann Rheum Dis 1989; 48: 864-70.

3 Blake D R, Merry P, Unsworth J, et al. Hypoxic-reperfusion injury in the inflamed human joint. Lancet 1989; i: 289-93.

4 Honkanen V, Konttinen Y T, Mussalo-Rauhamaa $\mathrm{H}$. Vitamins $\mathrm{A}$ and $\mathrm{E}$, retinol binding protein and zink in rheumatoid arthritis. Clin Exp Rheumatol 1989; 7: 465-9.

5 Knekt P Aroma A Matela J, et al Serum vitamin E and risk of cancer among Finnish men during a 10 year follow up. Am $\mathcal{7}$ Epidemiol 1988; 127: 28-41.

6 Aaran R-K, Nikkari T. HPLC method for the simultaneous determination of beta-carotene, retinol and alphatocopherol in serum. F Pharm Biomed Anal 1988; 6: 853-7.

7 Alfthan G, Kumpulainen J. Determination of selenium in small volumes of blood plasma and serum by electrothermal atomic absorption spectrometry. Anal Chim Acta 1982; 140: 221-7.

8 Gey K F, Brubacher G B, Stähelin H B. Plasma levels of antioxidant vitamins in relation to ischemic heart disease and cancer. Am F Clin Nutr 1987; 45: 1368-77.

9 Heliövaara $M$, Aho A, Aromaa A, Knekt P, Reunanen A. Smoking and risk of rheumatoid arthritis. $\mathcal{f}$ Rheumatol (in press).

10 Breslow N E, Day N E. Statistical methods in cancer research, Vol 1. The analysis of case-control studies. Lyon: IARC Scientific Publications 32, 1980: 248-79.

11 Järvinen R, Knekt P, Seppänen R, Heinonen M, Aaran R-K. Dietary determinants of serum beta-carotene and serum retinol. Eur f Clin Nutr 1993; 47: 31-41.

12 Hakala M, Pöllänen R, Nieminen P. The ARA 1987 revised criteria select patients with clinical RA from a populationbased cohort of subjects with chronic rheumatic diseases registered for drug reimbursement. F Rheumatol 1993; 20: 1674-8.

13 Aho K, Heliövaara M, Maatela J, Tuomi T, Palosuo T Rheumatoid factors antedating clinical rheumatoid arthritis. F Rheumatol 1991; 18: 1282-4. 